\title{
EVALUASI PEMENUHAN STANDAR TINGKAT KEBISINGAN KELAS DI SMPN 23 BANDUNG
}

\author{
Nur Metawati, Tjahyani Busono, Suhandy Siswoyo \\ Program Studi Pendidikan Teknik Arsitektur \\ FPTK Universitas Pendidikan Indonesia \\ Jl. Dr. Setiabudhi 207 Bandung
}

\begin{abstract}
Abstrak: Penelitian ini membahas tentang pemenuhan standar tingkat kebisingan di sekolah, dimana sekolah yang diteliti adalah SMPN 23 Bandung yang berlokasi di kawasan pasar tradisonal Ciroyom. Penelitian ini dilakukan dengan cara mengukur tingkat kebisingan menggunakan Sound Level Meter dengan mengambil empat kelas sampel yang diteliti dalam keadaan kosong yang dimaksudkan untuk mengetahui kondisi kebisingan pada jam efektif belajar mengajar (hening). Dari penyebab-penyebab kebisingan tersebut kemudian dicari solusi atau saran desain untuk mengurangi tingkat kebisingan. Hasil penelitian di kelas sampel A adalah sebesar $61 \mathrm{~dB}$, kelas sampel B adalah sebesar 58,3 dB, kelas sampel $\mathrm{C}$ adalah sebesar 53,5 dB, kelas sampel D adalah sebesar $56 \mathrm{~dB}$, disimpulkan bahwa terdapat Tiga kelas sampel yang tidak memenuhi standar tingkat kebisingan kementrian lingkungan hidup sebesar $55 \mathrm{~dB}$. Sumber kebisingan berasal dari kebisingan lalu lintas, kebisingan dari pemukiman padat penduduk, dan resonansi suara dilapangan yang diakibatkan oleh masa bangunan. Solusi yang digunakan untuk mereduksi kebisingan yang terjadi antara lain (1) menanam pohon di pagar depan sekolah, (2) menggunakan tamanan rambat disekitar pagar yang mengelilingi lapangan, (3) perubahan fungsi kelas dan organisasi ruang, (4) pengurangan presentase jendela dengan menggunakan glassblock yang menghadap ke batas pemukiman penduduk, (5) dan perubahan masa bangunan.
\end{abstract}

Kata Kunci : evaluasi pemenuhan standar, tingkat kebisingan, standar kebisingan

\begin{abstract}
This paper discusses the compliance of noise standard at school. Conducted at SMPN 23 Bandung, which is located close to the Ciroyom traditional market, the research measured noise level using Sound Level Meter. It took four empty classes as samples in order to identify the noise level during the effective learning and teaching hours (silence). As sources of noise are identified, the study then proposes design solutions. The study shows that the noise level in class A was $61 \mathrm{~dB}$, that in class B was $58,3 \mathrm{~dB}$, that in class $\mathrm{C}$ was $53,5 \mathrm{~dB}$, and that in class $\mathrm{D}$ was $56 \mathrm{~dB}$; thus, it is concluded that three of the sample classes do not meet the compliance of the Indonesia's Ministry of Environment, according to which the maximum noise level is $55 \mathrm{~dB}$. It also reveals that the sources of noise are nearby traffic, high density settlement, and the sounds at the nearby field that were resonated by the building masses surrounding it. Solutions that are proposed to reduce the noise are: (1) planting trees at the school's front fence, (2) planting vines onto the field fences, (3) re-organizing school's room layout, (4) reducing the percentage of windows at the building side facing the settlement by replacing them with glassblocks, (5) re-arranging the building masses.
\end{abstract}

Keywords: compliance to evaluation standard, noise level, noise standard level 


\section{PENDAHULUAN}

Kenyamanan akustik merupakan salah satu faktor penting dalam perancangan. Namun seseorang cenderung mengabaikan bising yang dihasilkannya sendiri bila bising itu wajar menyertai pekerjaan. Jika dibiarkan terlalu lama, akan berakibat buruk terhadap tubuh manusia. Bising berfrekuensi tinggi beresiko untuk merusak pendengaran seseorang. Badan kesehatan dunia di PBB mengatur tentang kebisingan dan mengeluarkan pernyataan bahwa kebisingan dapat mengganggu kesehatan seseorang "furthermore, noise has widespread psychosocial effects including noice annoyance, reduse performance, and increased aggressive behavior" (American Academy Of Pediatrics, 1997; WHO, 2001).

Jalur kereta dan mobil adalah dua tipe lalu lintas ramai dengan kendaraan dan menimbulkan bising yang dapat merusak telinga seperti yang ditulis dalam Architectural Acostic oleh Egan (2007) yaitu mencapai $100 \mathrm{~dB}$, sedangkan kebisingan yang diperbolehkan dalam sekolah adalah $55 \mathrm{~dB}$.

Ketenangan menghasilkan sebuah lingkungan yang meningkatkan daya pembelajaran siswa. Earthman (2004), menyatakan bahwa kebisingan suatu kelas pasti mengganggu proses belajar. Hal ini akan menimbulkan kesulitan bagi siswa untuk mencerna informasi yang diperoleh. Beliau mengatakan bahwa belajar dalam lingkungan bising akan lebih sulit bagi siswa pada dasarnya sudah sulit untuk fokus dalam belajar. Beliau juga mengatakan bahwa tingkat kebisingan moderat pada suatu kelas juga dapat mengganggu pembelajaran dan meningkatkan ketegangan dalam nada bicara guru. Studi lain dari Nelson (2001) membuktikan bahwa di London, kebisingan eksternal dapat memberikan dampak negatif pada standar penentuan skor dari ujian sekolah dasar di London. Studi ini menunjukan bahwa kebisingan eksternal mempengaruhi kecakapan berbicara di dalam kelas dan memiliki dampak yang besar dalam nilai ujian.

Kebisingan (noise) adalah bunyi atau suara yang tidak dikehendaki atau mengganggu.Gangguan bunyi hingga tingkat tertentu dapat diadaptasi oleh fisik, namun syaraf dapat terganggu.Ambang bunyi adalah intensitas bunyi sanagt lemah yang masih dapat didengar telinga manusia, berenergi $10^{-12} \mathrm{~W} / \mathrm{m}^{2}$.ambang bunyi ini 
disepakati mempunyai tingkat bunyi $0 \mathrm{~dB}$. Ambang sakit adalah kekuatan bunyi yang menyebabkan sakit pada telinga manusia, berenergi $1 \mathrm{~W} / \mathrm{m}^{2}$.

Tabel 1.Baku tingkat kebisingan berdasarkan Keputusan Menteri Negara Lingkungan Hidup, No.48 Tahun 1996

\begin{tabular}{llc}
\hline \multicolumn{1}{c}{ Bangunan } & \multicolumn{1}{c}{ Ruangan } & dBA \\
\hline Pendidikan & Ruang kelas, ruang kuliah & $30-40$ \\
& Ruang belajar privat & $20-35$ \\
& Perpustakaan & $35-45$ \\
\hline
\end{tabular}

Tabel 2. Kebisingan yang diperbolehkan standar Amerika

\begin{tabular}{cc}
\hline $\begin{array}{c}\text { Peruntukan Kawasan/ Lingkungan } \\
\text { Kesehatan }\end{array}$ & $\begin{array}{c}\text { Tingkat kebisingan } \\
\text { dB (A) }\end{array}$ \\
\hline Lingkungan Kegiatan & 55 \\
1. Rumah sakit atau sejenisnya & 55 \\
2. Sekolah atau sejenisnya & 55 \\
3. Tempat ibadah atau sejenisnya & 5 \\
\hline
\end{tabular}

\section{Strategi Umum Penanganan Kebisingan}

a. Langkah awal selalu menangani kebisingan pada sumbernya dengan cara mengatur sedemikian rupa agar sumber bunyi mengeluarkan intensitas bunyi minimal. Bila memungkinkan, bungkamlah sumber kebisingan dengan cara memberikan penutup yang melingkupi sumber tadi dari bahan yang memiliki hambatan suara tinggi (TL besar, kehilangan transmisi besar)

b. Bila tidak memungkinkan menangani sumber kebisingan langsung, maka tangani media rambat bunyi. Getaran mesin dapat merambat melalui lantai yang akan menjadi kebisingan diruang lain. Pemakaian pegas atau perdam getaran langsung pada mesin akan memotong rambatan bunyi. Permukaan-permukaan yang tidak memantulkan bunyi akan sangat membantu mengurangi kebisingan.

c. Jika kedua hal diatas tidak memungkinkan, maka terpaksa penanganan kebisingan dilakukan pada penerima bunyi. Pelindungan telinga (ear protector) sangat dibutuhkan untuk melindungi telinga dari ketulian akibat kebisingan yang berat. 


\section{Peredam Bunyi Yang Efektif}

Menurut Ergan dalam memakai peredam bunyi adalah sebagai berikut :

a. Pasanglah bahan-bahan peredam bunyi pada permukaan yang dapat menyebabkan waktu dengung berlebihan, gema mengganggu, dan titik api bunyi. Waktu dengung yang berlebihan akan sangat mengganggu kejelasan percakapan, terutama bagi orang dengan alat bantu pendengaran dan orang tua. Mengandalkan luas permukaan peredam akan mengurangi waktu dengung hingga setengahnya.

b. Jangan menggunakan bahan peredam bunyi pada permukaan yang dapat bermanfaat sebagai pemantul seperti pada bidang diatas podium auditorium. Permukaan pemantul bunyi sebaiknya mempunyai koefisien serapan dibawah 0,2 dan dibentuk sedemikian rupa untuk mengarahkan bunyi

c. Jika lantai tidak berkarpet dinding tidak dilapis gorden tebal, dan diruangan tidak terdapat perabot yang dapat meredam bunyi, gunakanlah langit-langit sebagai pengendali kebisingan. Saat ini sudah banyak tersedia bahan-bahan peredam bunyi untuk langit-langit yang tahan api, memantulkan cahaya, dan menarik secara arsitektural.

d. Tempatkan peredam pada dinding-dinding ruang yang sangat tinggi, kecil, lorong yang panjang dan sempit, yang cenderung menciptakan flutter echo( suara gema cepat).

e. Perhatikan baik-baik detail konstruksi pemegang bahan peredam karena sangat berpengaruh terhadap efektifitas peredam.

f. Jangan berlebihan menganggap bahwa bahan peredam bunyi akan banyak mngurangi intensitas bunyi sebab bahan peredam digunakan untuk mengurangi pemantulan. Harus menggandakan luas bahan peredam untuk mengurangi instensitas bunyi sebanyak $3 \mathrm{~dB}$, membutuhkan banyak penambahan luasan jika ini=gin mnegurangi hingga $6 \mathrm{~dB}$. Oleh karena itu dalam banyak situasi, pengurangan 3-6 $\mathrm{dB}$ dianggap sebagai batas praktis pengurangan kebisingan dengan bantuan bahan peredam bunyi. 
Setiap kelas mempunyai tingkat kebisingan yang berbeda-beda. Di SMPN 23 Bandung terdapat sumber bising yang sukar untuk dihilangkan. Sumber bising tersebut adalah lapangan olah raga, jika terdapat aktifitas di lapangan tersebut. Suarasuara yang berasal dari lapangan akan terpantul kembali karena orientasi bangunan yang berbentuk huruf $\mathrm{O}$ sehingga suara terdengar bising yang akan mengganggu proses belajar didalam kelas.

\section{METODE}

Metode penelitian yang digunakan adalah metode deskriptif dan evaluatif.Metode deskriptif digunakan dalam penelitian awal untuk menghimpun data tentang kondisi eksisiting. Metode evaluatif digunakan untuk mengevaluasi proses pengembangan dan produk yang dihasilkan. Data yang dihasilkan berupa angkaangka hasil pengamatan dilapangan secara langsung, setelah data terkumpul kemudian dideskriptifkan, dibandingkan dengan standar yang ada, setelah itu dibuatkan solusi yang konkrit.

\section{HASIL DAN PEMBAHASAN}

Penelitian dilakukan di SMPN 23 Bandung yang berlokasi di Jalan Arjuna no. 20-22 Bandung. Kelas yang digunakan untuk sampel penelitian adalah sebanyak empat kelas yang dapat mewakili kondisi kebisingan ruang luar setiap blok di gedung SMPN 23 Bandung.

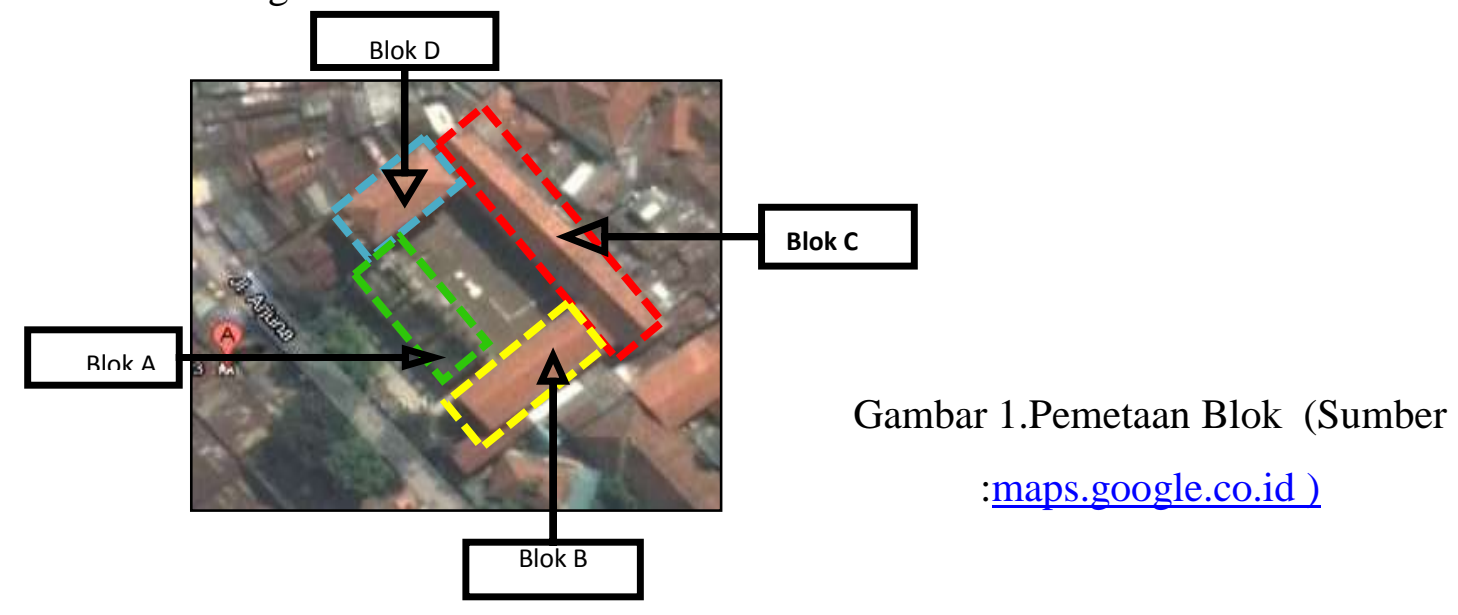



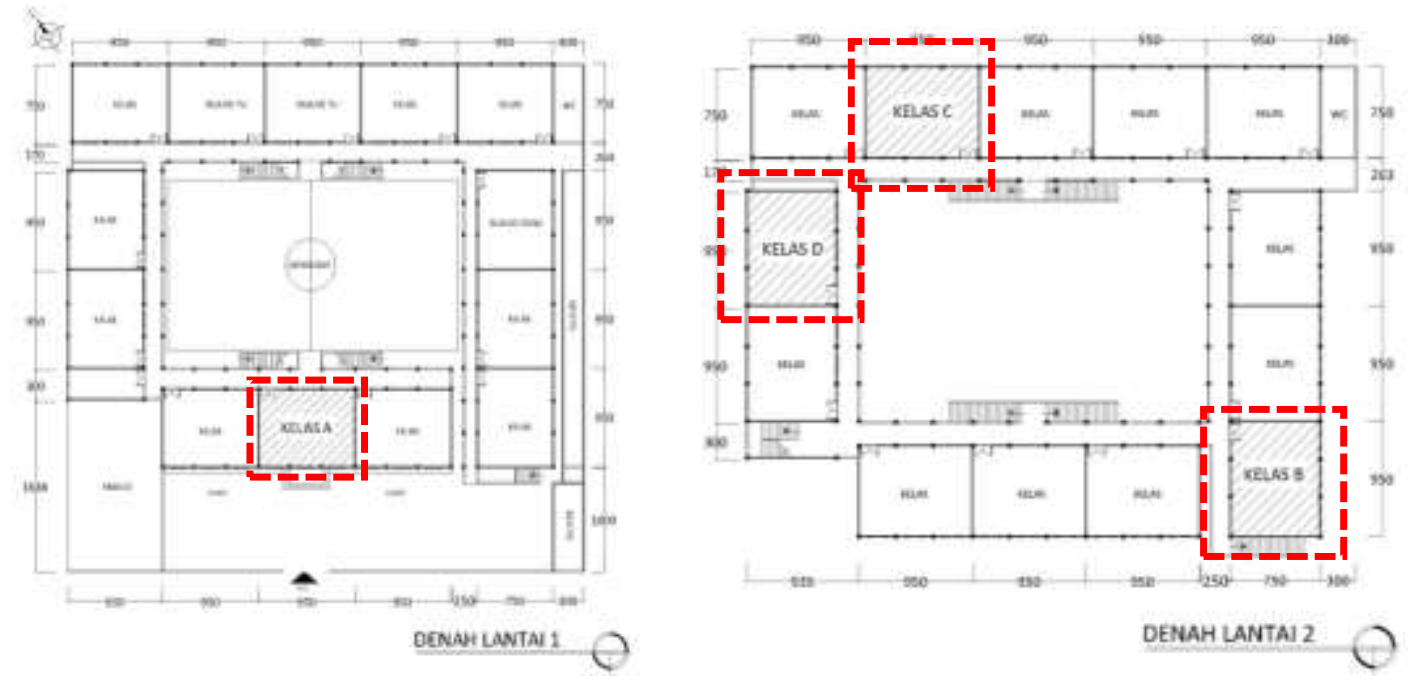

Gambar 2. Denah SMPN 23 Bandung dan Lokasi Kelas Sampel

\section{Hasil Penelitian Kelas Sampel A}

Pengukuran tingkat kebisingan menggunakan instrumen Sound Level Meter, yang diukur di sembilan titik pada setiap kelas sampel. Kondisi ruang kelas A terletak di lantai satu yang langsung berhadapan dengan gerbang sekolah dan jalan raya, dengan keadaan bukaan total pada sisi dinding barat dan dinding timur kelas untuk memaksimalkan cahaya alami dan sirkulasi udara yang baik. Luas ruang kelas A adalah 71,25 $\mathrm{m}^{2}$ dengan panjang kelas 9,5m dan lebar kelas 7,5m dengan ketinggian plafond $\pm 3 \mathrm{~m}$ (lihat gambar 4). Kelas A dapat menampung 40 siswa.

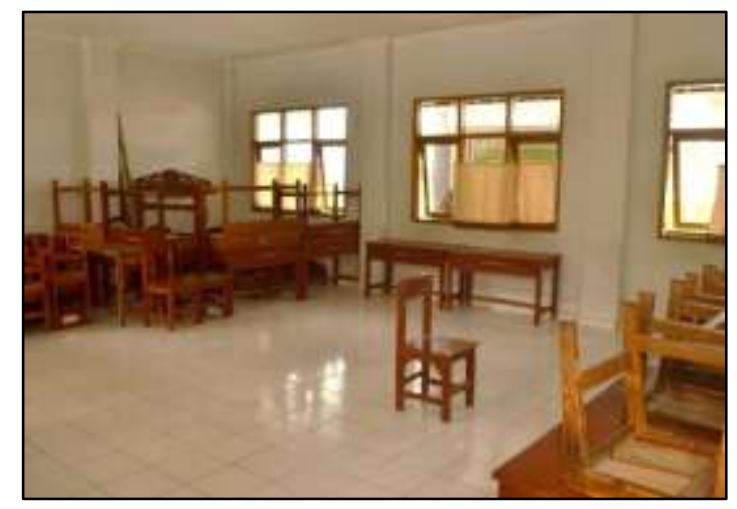

Gambar 3.Kelas Sampel A 
Keadaan kelas A dapat dilihat pada gambar 3. Terdapat bukaan jendela dan ventilasi sekitar 50\% di kedua sisi kelas, satu sisi bukaan menghadap ke arah gerbang dan satu sisi bukaan menghadap ke arah lapangan. Kondisi kelas disini sangat bising karena kedua bukaan jendela mengarah kepada sumber kebisingan. Pada sisi utara akan sangat bising jika terdapat aktifitas di lapangan (lihat gambar 4), dan pada sisi selatan (lihat gambar 5) akan bising oleh kendaraan yang lalu lalang.

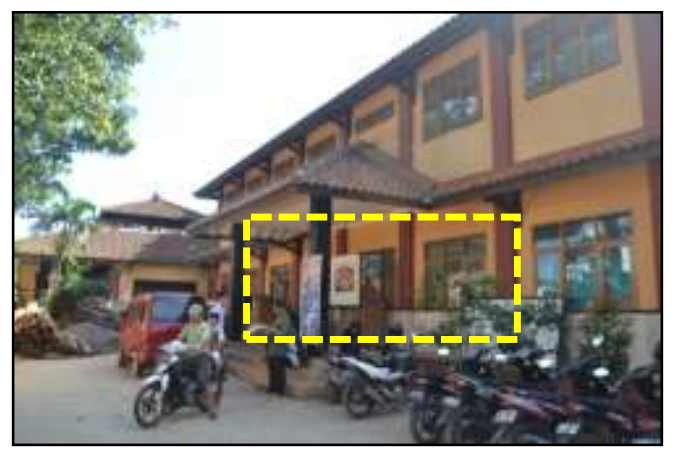

Gambar 4. Bukaan jendela sisi utara

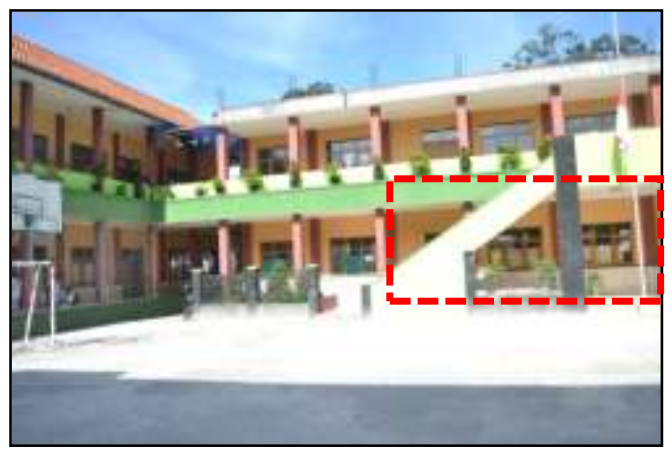

Gambar 5. Bukaan jendela sisi selatan

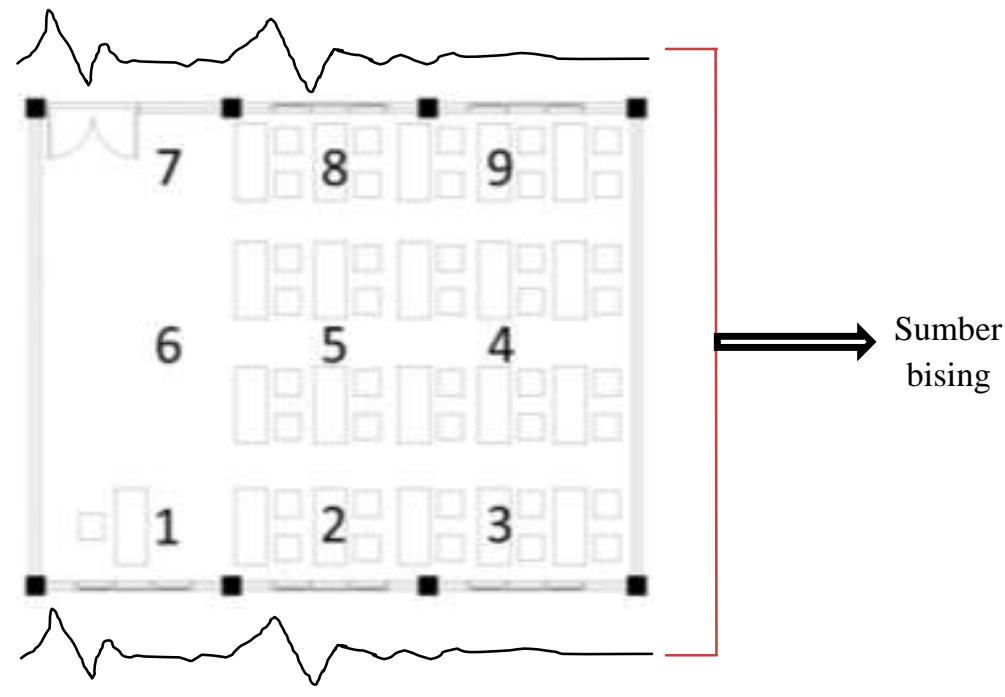

Gambar 6. Sumber bising dan titik pengukuran

Pengukuran kebisingan menggunakan alat Sound Level Meter yang disimpan di titik - titik pengukuran per-5 detik dalam satu menit. Maka dihasilkan angka angka seperti terlihat pada tabel 3 . 
Tabel 3. Hasil pengukuran tingkat kebisingan kelas sampel A

\begin{tabular}{cccccccccccc}
\hline KELAS A & \multicolumn{10}{c}{ TITIK } & \multicolumn{10}{c}{$\begin{array}{c}\text { rata- } \\
\text { rata }\end{array}$} & $\begin{array}{c}\text { dBA } \\
\text { (tertinggi) }\end{array}$ \\
\cline { 2 - 7 } & $\mathbf{1}$ & $\mathbf{2}$ & $\mathbf{3}$ & $\mathbf{4}$ & $\mathbf{5}$ & $\mathbf{6}$ & $\mathbf{7}$ & $\mathbf{8}$ & $\mathbf{9}$ & \\
\hline $08.00-09.00$ & 61.8 & 61.1 & 60.0 & 58.5 & 58.3 & 58.3 & 62.2 & 61.3 & 64.1 & 60.6 & 74 \\
$09.00-10.00$ & 61.2 & 61.6 & 55.5 & 63.3 & 61.3 & 60.4 & 58.8 & 59.5 & 60.3 & 60.2 & 75 \\
$10.00-11.00$ & 62.3 & 62.8 & 63.8 & 59.3 & 61.7 & 61.3 & 65.6 & 62.2 & 61.3 & 62.2 & 75 \\
$11.00-12.00$ & 64.8 & 64.4 & 63.0 & 62.5 & 61.1 & 63.8 & 60.5 & 61.6 & 61.1 & 62.5 & 76 \\
$12.00-13.00$ & 63.0 & 65.0 & 61.0 & 58.9 & 53.9 & 53.5 & 56.3 & 57.4 & 62.5 & 59.1 & 72 \\
$13.00-14.00$ & 61.5 & 65.5 & 60.8 & 56.3 & 58.1 & 59.3 & 58.4 & 65.0 & 58.3 & 60.3 & 72 \\
\hline
\end{tabular}

Berdasarkan Baku tingkat kebisingan berdasarkan Keputusan Menteri Negara Lingkungan Hidup, No.48 Tahun 1996 ditetapkan untuk tingkat kebisingan yang diperbolehkan untuk bangunan sekolah adalah $55 \mathrm{~dB}$, sedangkan menurut Koenigsbergerkebisingan yang diperbolehkan adalah 30-40 dB. Berikut ini hasil analisis data yang dari penelitian yang dilakukan pada hari sabtu, 9 Juni 2013 :

Tabel 4.Tabel analisis data kelas A

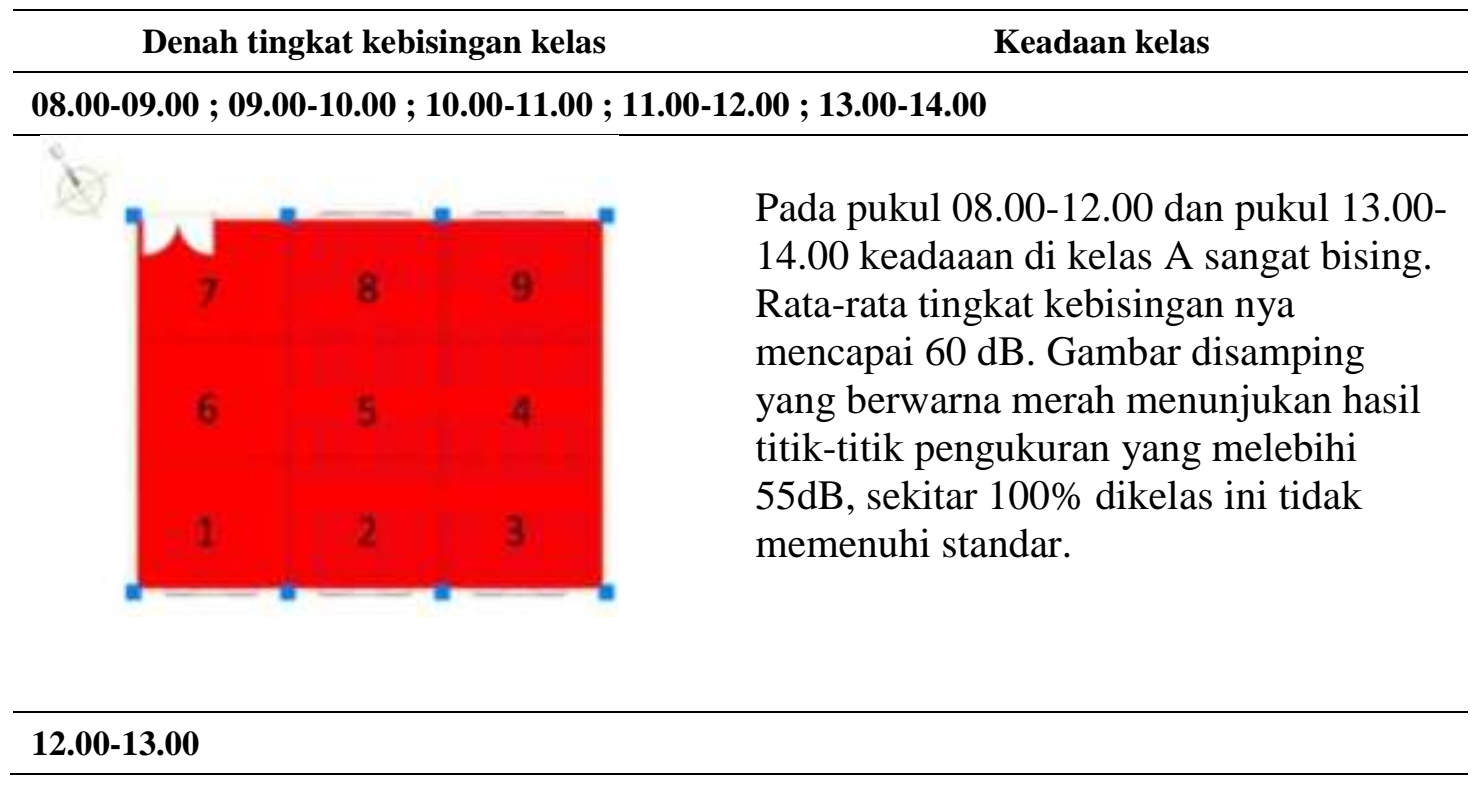




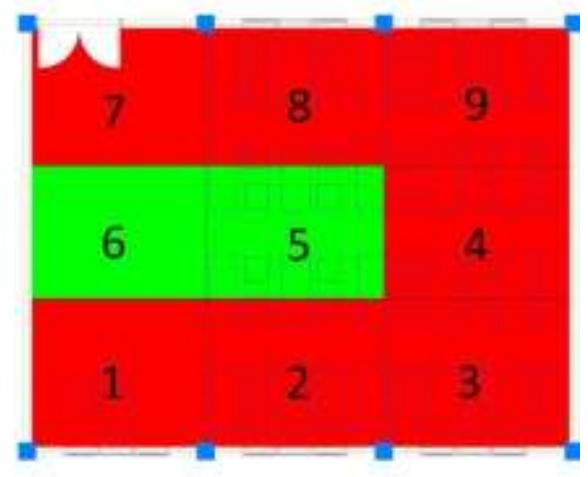

Pada pukul 12.00-13.00 keadaaan di kelas A sangat bising. Rata-rata tingkat kebisingan mencapai $59 \mathrm{~dB}$ namun tidak sebising pada pagi hari. Gambar disamping yang berwarna merah menunjukan hasil titik-titik pengukuran sekitar 78\% kondisi kelas tidak memenuhi standar, sedangkan titik berwarna hijau menunjukan $22 \%$ memenuhi standar 55dB.

keterangan :

Tidak memenuhi standar (56- $76 \mathrm{~dB}$ )

Memenuhi standar (51- 55 dB)

Diatas standar $(50$ - $40 \mathrm{~dB})$

Kesimpulan :

Kesimpulan dari analisis data diatas adalah kebisingan berasal dari bising lalu lintas dan bising dari aktifitas di lapangan, dan menunjukan bahwa kelas A 96\% tidak memenuhi standar Keputusan Menteri Negara Lingkungan Hidup, No.48 Tahun 1996. Menurut penulis dari hasil penelitian dilapangan, kelas yang nyaman adalah kelas yang memiliki tingkat kebisingan maksimal $50 \mathrm{~dB}$.

\section{Kelas Sampel C}

Pengukuran kebisingan menggunakan alat Sound Level Meter yang disimpan di titik - titik pengukuran per-5 detik dalam satu menit. Maka dihasilkan angka angka berikut ini :

Tabel 5. Hasil pengukuran tingkat kebisingan kelas sampel C

\begin{tabular}{|c|c|c|c|c|c|c|c|c|c|c|c|}
\hline \multicolumn{12}{|l|}{ KELAS C } \\
\hline \multirow{2}{*}{ WAKTU } & \multicolumn{9}{|c|}{ TITIK } & \multirow{2}{*}{$\begin{array}{l}\text { rata- } \\
\text { rata }\end{array}$} & \multirow{2}{*}{$\begin{array}{c}\mathrm{dBA} \\
\text { (tertinggi) }\end{array}$} \\
\hline & 1 & 2 & 3 & 4 & 5 & 6 & 7 & 8 & 9 & & \\
\hline 08.00-09.00 & 51.2 & 47.8 & 51.7 & 48.3 & 48.6 & 50.5 & 51.5 & 53.2 & 53.1 & 50.6 & 71 \\
\hline $09.00-10.00$ & 54.5 & 53.2 & 49.6 & 52.1 & 53.8 & 51.9 & 48.8 & 49.4 & 49.9 & 51.5 & 73 \\
\hline $10.00-11.00$ & 56.6 & 59.9 & 57.5 & 51.5 & 53.3 & 55.1 & 57.0 & 52.8 & 54.8 & 55.4 & 70 \\
\hline $11.00-12.00$ & 57.0 & 56.7 & 56.3 & 55.9 & 57.1 & 56.9 & 58.5 & 58.7 & 57.6 & 57.2 & 67 \\
\hline $12.00-13.00$ & 54.0 & 54.3 & 55.3 & 53.2 & 51.3 & 51.7 & 45.8 & 47.3 & 48.4 & 51.2 & 64 \\
\hline $13.00-14.00$ & 58.4 & 58.1 & 57.9 & 52.2 & 55.8 & 51.9 & 52.2 & 53.2 & 56.1 & 55.1 & 71 \\
\hline
\end{tabular}




\section{Kelas Sampel D}

Pengukuran kebisingan menggunakan alat Sound Level Meter yang disimpan di titik - titik pengukuran per-5 detik dalam satu menit. Maka dihasilkan angka angka berikut ini :

Tabel 6. Hasil pengukuran tingkat kebisingan kelas sampel D

\begin{tabular}{|c|c|c|c|c|c|c|c|c|c|c|c|}
\hline \multicolumn{12}{|l|}{ KELAS D } \\
\hline \multirow{2}{*}{ WAKTU } & \multicolumn{9}{|c|}{ TITIK } & \multirow{2}{*}{$\begin{array}{c}\text { rata- } \\
\text { rata }\end{array}$} & \multirow{2}{*}{$\begin{array}{c}\mathrm{dBA} \\
\text { (tertinggi) }\end{array}$} \\
\hline & 1 & 2 & 3 & 4 & 5 & 6 & 7 & 8 & 9 & & \\
\hline 08.00-09.00 & 61.8 & 57.3 & 56.5 & 51.1 & 53.4 & 48.7 & 48.3 & 52.0 & 55.8 & 53.9 & 69 \\
\hline $09.00-10.00$ & 52.7 & 54.3 & 55.3 & 51.6 & 51.2 & 56.8 & 54.8 & 57.2 & 54.2 & 54.2 & 74 \\
\hline $10.00-11.00$ & 56.8 & 55.5 & 55.2 & 61.3 & 56.4 & 58.3 & 57.2 & 60.1 & 54.3 & 57.2 & 78 \\
\hline $11.00-12.00$ & 61.1 & 56.2 & 57.3 & 56.0 & 57.2 & 59.6 & 57.6 & 60.2 & 55.2 & 57.8 & 70 \\
\hline $12.00-13.00$ & 55.0 & 58.8 & 56.2 & 56.3 & 57.5 & 56.0 & 55.4 & 56.1 & 57.9 & 56.6 & 70 \\
\hline $13.00-14.00$ & 54.8 & 59.1 & 55.3 & 52.1 & 53.7 & 51.8 & 54.3 & 52.6 & 54.4 & 54.2 & 74 \\
\hline
\end{tabular}

\section{Diagram Perbandingan Tingkat Kebisingan Di SMPN 23 Bandung}

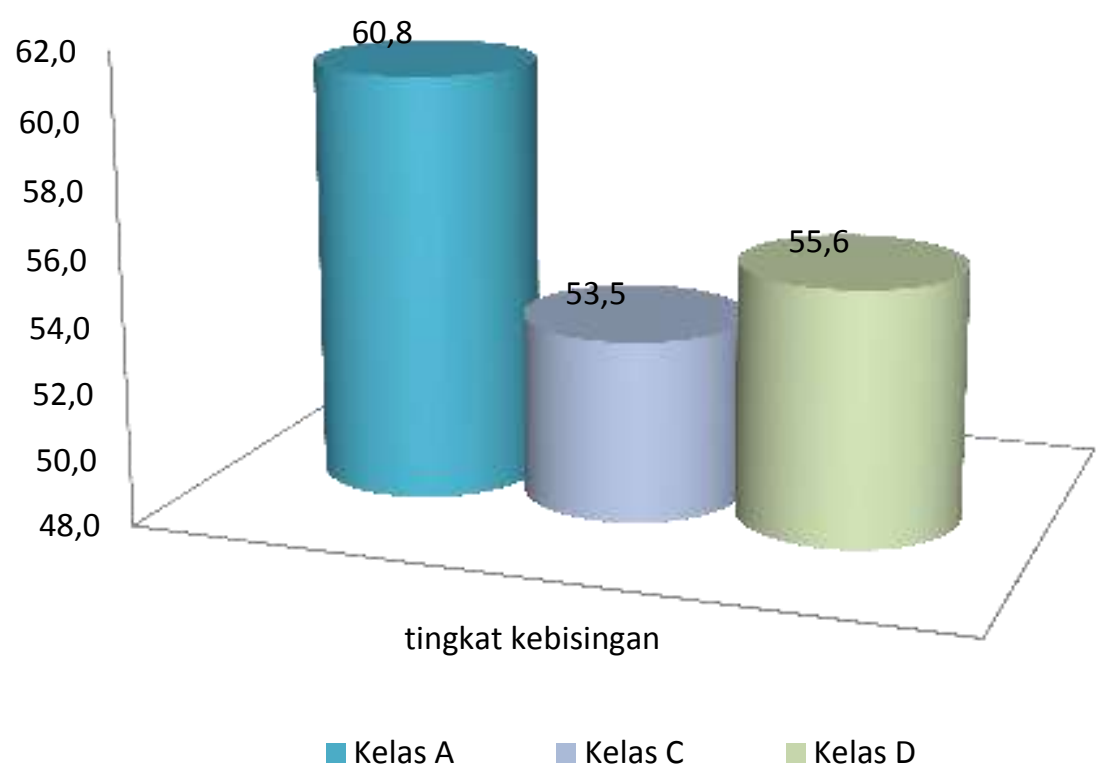

Gambar 7. Perbandingan Tingkat Kebisingan Di SMPN 23 Bandung 
Berdasarkan penelitian dan pengukuran di lapangan kelas yang merupakan kelas dengan tingkat kebisingan paling tinggi yaitu kelas A dengan kebisingan $61 \mathrm{~dB}$ dan 96\% tidak memenuhi standar Kementrian Lingkungan Hidup.

Kelas B merupakan kelas terbising ke dua setelah kelas A, dengan tingkat kebisingan rata-rata 58,3 dB dan $80 \%$ tidak memenuhi standar Kementrian Lingkungan Hidup. Kelas C dan kelas D merupakan kelas dengan tingkat kebisingan yang rendah, masing-masing sebesar 53,5 dB dan 55,6 dB.

\section{Sumber Bising}

Lokasi sekolah berada dikawasan padat yang menimbulkan kebisingan sehingga dapat mengganggu konsentrasi siswa saat proses belajar mengajar berlangsung. Dari penelitian yang dilakukan ditemukan sumber-sumber kebisingan antara lain, (a) kebisingan lalu lintas, (b) kebisingan kereta api, (c) kebisingan dari pengeras suara di pemukiman penduduk, dan (d) kebisingan akibat resonansi masa bangunan.

Berdasarkan hasil penelitian dan pengamatan diatas ditemukan permasalahpermasalahan kebisingan yang terjadi di SMPN 23 Bandung yang kemudian akan dibuatkan solusi nya, Langkah awal selalu menangani kebisingan pada sumbernya dengan cara mengatur sedemikian rupa agar sumber bunyi mengeluarkan intensitas bunyi minimal, diantaranya adalah (a) penanaman pohon, (b) penggunaan pagar dengan tanaman rambat, (c) perubahan fungsi kelas, (d) pengurangan presentase bukaan (jendela), dan (e) perubahan masa bangunan.

\section{KESIMPULAN}

Lokasi sekolah SMPN 23 Bandung mengalami kebisingan dengan sumbersumber kebisingan antara lain; lalu lintas, bising pengeras suara, pintu perlintasan kereta api, dan aktifitas lapangan sekolah.

Kelas A yang merupakan perwakilan dari blok A mempunyai bukaan jendela dan ventilasi sekitar 50\% di kedua sisi kelas, satu sisi bukaan menghadap ke arah utara (lapangan sekolah) dan satu sisi bukaan menghadap ke arah selatan (gerbang 
sekolah). Sumber kebisingan dari kelas ini yaitu arus lalu lintas didepan sekolah, dengan GSB yang berjarak 10m ini masih terdengar suara kendaraan yang melintas di depan sekolah. Sumber kebisingan yang lain adalah aktifitas di lapangan, karena kelas berada tepat didepan lapangan. Tingkat kebisingan kelas A mencapai $61 \mathrm{~dB}$ yang melebihi standar Kementrian Lingkungan Hidup yang sebesar 55 dB. Kelas A mendapatkan presentase $96 \%$ tidak memenuhi standar.

Kelas $\mathrm{C}$ yang merupakan perwakilan dari blok $\mathrm{C}$ mempunyai bukaan jendela dan ventilasi sekitar $40 \%$ bukaan di sisi selatan (lapangan), dan $10 \%$ bukaan di sisi utara (pemukiman penduduk). Sumber kebisingan dari kelas ini yaitu aktifitas di lapangan dan suara sirine kereta api. Tingkat kebisingan kelas C mencapai 53,5 dB yang mencapai standar Kementrian Lingkungan Hidup yang sebesar 55 dB. Kelas C mendapatkan presentase $73 \%$ memenuhi standar.

Kelas D yang merupakan perwakilan dari blok D mempunyai bukaan jendela dan ventilasi sekitar $50 \%$ bukaan di sisi timur (lapangan), dan 10\% bukaan di sisi utara (pemukiman penduduk dan pasar). Sumber kebisingan dari kelas ini yaitu aktifitas di lapangan dan suara sirine kereta api. Tingkat kebisingan kelas C mencapai $56 \mathrm{~dB}$ yang melebihi standar Kementrian Lingkungan Hidup yang sebesar 55 dB. Kelas D mendapatkan presentase $50 \%$ memenuhi standar.

\section{DAFTAR PUSTAKA}

Doelo, Leslie., Prasetio, Lea. 1972. Akustik Bangunan. Jakarta : Erlangga.

Earthman, Glen I,(2004) Prioritazion of 31 Criteria for School Building Adequance.

Grey dan Deneke Frederick, (1978).Urban Forestry Publisher, Krieger Publishing Company

Egan, M. D., (2007) Architectural acoustics, J. Ross Publishing Classics

Nelson, P, 2001, ANSI-S12.60-2002, Standar Nasional Akustik Bangunan Sekolah, New York, Acoustical Society of America (ASA). 